\title{
How Do We Know How Students Experience Higher Education? On the Use of Student Surveys
}

\author{
Manja Klemenčič and Igor Chirikov
}

\section{Introduction}

We do not yet fully understand what is going on with students while they are enrolled in higher education. This is problematic. There are about 197 million students today globally, and UNESCO's prediction is that this number will rise to 262 million by $2025 .{ }^{1}$ The opportunity costs - both for individual students and our economies and societies - are enormous if higher education institutions do not fulfill their promise of formative effects on students because they do not have sufficient information and knowledge of what, why and how students learn and develop in higher education context. These questions are of central importance for university officials, for prospective students and their families, and for the state as the main funder of higher education in Europe.

Quality educational provision and learning environment can render most rewarding learning experiences. Equally, poor educational conditions incur significant cost of missed learning opportunities and unsatisfactory student experience. Student experience has thus become a central tenet of the quality assurance in higher education. More recently, the attention has shifted from student experience to student engagement (Klemenčič 2015) which conceives students as active partners in educational process and as responsible for their own learning and formation. In this vein, higher education is understood as "a process of student self-formation": the activities students engage in are all in some way or another

${ }^{1}$ UNESCO Institute of Statistics: http://uis.unesco.org/.

\section{Klemenčič $(\square)$}

Harvard University, Cambridge, MA, USA

e-mail: manjaklemencic@fas.harvard.edu

I. Chirikov

National Research University Higher School of Economics, Moscow, Russia

e-mail: igor.chirikov@gmail.com

A. Curaj et al. (eds.), The European Higher Education Area,

DOI 10.1007/978-3-319-20877-0_24 
geared towards changing themselves and their life circumstances (Marginson 2014). Student self-formation is the basis for achieving the broader societal objectives concerned with human capital development for economic purposes: developing skills, improving productivity, increasing potential for innovation and economic growth. It also relates to the societal objectives towards secure, democratic, healthy societies. If, as defined by Hall and Lamont (2009, p. 2), a "successful society" is "one that enhances the capabilities of people to pursue the goals important to their own lives, whether through individual or collective action", then education which enables and strengthens student agency is both a condition of a successful society, and also one of the outcomes of it. Institutional decision makers and policy makers thus seek to understand student experiences and behaviors as to be able to develop interventions that will further enhance "student agency" towards self-formation (Klemenčič 2015).

Student surveys have become one of the largest and most frequently used data source for quality assessment in higher education (Williams 2014). Student survey data feed into evidence-based university decision-making and are part of the tasks of institutional research. Institutional researchers are asked by university officials to deliver more and better "intelligence" on students (Klemenčič and Brennan 2013; Klemenčič et al. 2015). Much of this data is acquired through student surveys. As noted by David Radwin in Chronicle of Higher Education (Radwin 2009) “...the use of surveys is one of the fastest-growing and most pervasive trends on campuses". Technology has made it increasingly possible to collect data from students: it is cheap, fast and easy to process. Indeed, students are perhaps among the most surveyed populations world-wide.

The widespread use of student survey data raises questions of reliability and validity of student survey data as evidence in decision-making. In this chapter we first discuss the policy context in which student survey research has proliferated. Then we offer an overview of the most influential student experience and engagement surveys; followed by a discussion of methodological limitations of survey research. The penultimate section addresses student surveys as part of the development of student data analytics, as the practices of collecting, synthesizing, and analyzing student data in the context of institutional research. We conclude with a set of recommendations on quality standards for survey design, and the use of student survey data as evidence in decision-making.

\section{The Changing Policy Context and Demand for Data on Students}

The range of data gathered on students has expanded significantly over the years (see Table 1 for the types of student surveys and examples). The basic statistical data on students has typically included data on student enrollments and student 
Table 1 Most common student surveys

\begin{tabular}{|c|c|}
\hline Types of surveys & Examples of most influential or international surveys \\
\hline Student profiles & EUROSTUDENT $^{\mathrm{a}}$ \\
\hline $\begin{array}{l}\text { Assessment of student learning } \\
\text { outcomes }\end{array}$ & $\begin{array}{l}\text { OECD's Assessment of Higher Education Learning } \\
\text { Outcomes (AHELO) } \\
\text {; ; United States Collegiate Learning } \\
\text { Assessment (CLA) (Shavelson 2010), The Educational } \\
\text { Testing Services' Proficiency Profile (ETS 2014; Coates } \\
\text { and Lennon 2014) }\end{array}$ \\
\hline Student course evaluations & Institution/study-program-based \\
\hline $\begin{array}{l}\text { Student approaches to learning } \\
\text { and studying }\end{array}$ & $\begin{array}{l}\text { ASSIST (Approaches and Study Skills Inventory for } \\
\text { Students) }{ }^{\text {c }} \text {; The Study Process Questionnaire (Biggs } \\
\text { 1987a); The Learning Process Questionnaire (Biggs } \\
\text { 1987c) }\end{array}$ \\
\hline $\begin{array}{l}\text { Student experience (satisfaction) } \\
\text { and engagement surveys }\end{array}$ & $\begin{array}{l}\text { The North American National Survey of Student } \\
\text { Engagement (NSSE), which has been adapted into a } \\
\text { number NSSE-based national surveys }{ }^{\mathrm{e}} \text {; Australasian } \\
\text { Survey of Student Engagement (AUSSE); Student } \\
\text { Experience in the Research University (SERU) } \\
\text { National Student Survey in the UK (NSS) }{ }^{\mathrm{h}} \text {; Dutch } \\
\text { National Student Survey (NSE) }{ }^{\mathrm{i}} \text {; Irish Survey of Student } \\
\text { Engagement (ISSE) }\end{array}$ \\
\hline Student mobility surveys & International Student Barometer Survey ${ }^{\mathrm{k}}$ \\
\hline Graduate employment surveys & Accenture College Graduate Employment Survey ${ }^{1}$ \\
\hline
\end{tabular}

${ }^{a}$ http://www.eurostudent.eu/

bhttp://www.oecd.org/edu/skills-beyond-school/

testingstudentanduniversityperformancegloballyoecdsahelo.htm

${ }^{c}$ http://www.etl.tla.ed.ac.uk/questionnaires/ASSIST.pdf

${ }^{\mathrm{d}}$ http://nsse.iub.edu/

${ }^{\mathrm{e}}$ NSSE-based surveys were administered in Australia, China, South Africa, the UK, Ireland and several other countries (Coates and McCormick 2014)

f http://www.acer.edu.au/ausse

${ }^{\mathrm{h}} \mathrm{htt}: / /$ www.cshe.berkeley.edu/SERU

hhttp://www.thestudentsurvey.com/

${ }^{\mathrm{i}} \mathrm{http} / / /$ www.uu.nl/EN/informationfor/students/facilities/NSE/Pages/default.aspx

${ }^{\mathrm{j}} \mathrm{http}: / /$ studentsurvey.ie/wordpress/

${ }^{k}$ http://www.i-graduate.org/

${ }^{\mathrm{h}} \mathrm{http} / / / \mathrm{www}$.accenture.com/us-en/Pages/insight-2014-accenture-college-graduate-employment-

survey.aspx

profiles (gender, nationality, socio-economic background). Later, student course evaluations were introduced, followed by data on student approaches to learning, and assessment of student learning. Within European policy context, the EU support for the large international comparative survey on students' socio-economic background reflects the European Unions' concerns over educational equity. Surveys focusing specifically on the experience of international students also emerged following the internationalisation of higher education, and especially EU mobility schemes (Erasmus) and the efforts by institutions and government to attract foreign fee-paying students. 
Within the European Higher Education Area, the emphasis on the student-centered approach paved the way for further and more extensive inquiries into how students learn (through surveys of student approaches to learning), what we expect them to learn (e.g. Tuning project defining learning outcomes and competences in specific study areas ${ }^{2}$ and the European Qualifications Framework ${ }^{3}$ ), and how do we know that expected learning happened (Coates and Lennon 2014). As student learning and development became more closely associated with institutional quality, this boosted higher education research on student satisfaction, and student engagement in educationally purposeful activities.

The origins of student satisfaction surveys lie in student evaluations of course teaching (Ramsden 1991), which have a fairly long tradition in all higher education systems. These evaluations have been gradually extended to also include student perceptions on quality of institutional conditions supporting teaching and learning, such as libraries, student support services, etc. As Harvey (2003, p. 3) suggests, institutional decisions makers seek feedback from students. Harvey (2003, p. 3) defines "feedback" as the "expressed opinions of students about the service they receive as students", and this may include "perceptions about the learning and teaching, the learning support facilities (such as libraries, computing facilities), the learning environment, (lecture rooms, laboratories, social space and university buildings), support facilities (refectories, student accommodation, health facilities, student services) and external aspects of being a student (such as finance, transport infrastructure)". The levels of analysis have also extended from individual courses to modules, and study programs to institution-level satisfaction surveys of the entire study experience (see Harvey 2003 for recommendations for survey management at each level). Both student course and program evaluations, which are more focused on satisfaction with teaching and learning, and the surveys of overall study experience, have been integrated into - and are an essential ingredient of - internal institutional quality assurance systems. Indeed, the European University Association's study shows that student questionnaires "are the most common way for institutions to introduce quality assurance processes" (Loukolla and Zhang 2010 , p. 27). Reports from the student satisfaction surveys are also required in external quality assurance processes and accreditation.

However, student satisfaction surveys have been criticized for conceiving students as passive recipients of educational services, rather than actively engaged in their learning and development. This criticism gave rise to developments of student engagement surveys. Unlike student satisfaction surveys, the assessment of student engagement measures the extent to which students participate in educationallypurposeful activities (i.e. those that are expected to enhance learning and development), and the support they receive from teachers and institutions to do so (Kuh 2009). Many have argued in favor of investigating student engagement for higher education quality assurance (Coates 2005), and the concept of student engagement

\footnotetext{
${ }^{2}$ http://tuning.unideusto.org/tuningeu/.

${ }^{3}$ http://ec.europa.eu/ploteus/content/descriptors-page.
} 
has become "central to most contemporary understandings of student experience and to debates regarding quality enhancement" (Callender et al. 2014, p. 31).

Quality enhancement, which has a predominant place among the policy priorities within the European Higher Education Area, has important implications for data collection on student experience and engagement. Student engagement and experience surveys have been hailed as a driver of institutional reforms towards improvement in students' experience, for example through improvements in student support services, student facilities, and in teaching and assessment (Richardson 2013). Student survey data is increasingly used also for external purposes. Governments use such data as part of accountability checks on institutional performance (Klemenčič et al. 2015). The existing measures of institutional performance have relied predominantly on the attainment levels (graduation rates, retention rates). The trend now is to evaluate the institutional performance also from the point of view of the added value that higher education brings to the students individually and collectively. One way to assess this is to ask students directly about their experiences. The other way is to assess student learning outcomes so as to establish if knowledge and skills are of expected standards, and meet the employers' expectations and the needs of knowledge societies. Data obtained directly from students as the primary users of the educational services is seen as more accurate estimate of the performance of the higher education institutions than when performance is measured only by student attainment (cf. Kim and Lalancette 2013).

The proliferation of student surveys is thus part of the growing trend towards evidence-based movement in higher education with focus on institutional performance. It is also a reflection of growing competition in higher education. Institutions also gather data from students to benchmark their performance against peer institutions. They use survey data in public relations and recruitment. Governments use student experience surveys as a "transparency tool" to inform students' choice in rising competition between higher education providers to attract fee-paying students (Harvey 2003). Notably, global ranking agencies so far do not put a lot of pressure on universities to collect and provide student-related data despite the fact that all of them declare they are created to inform students' choices in higher education. ${ }^{4}$ An exception is the recent international ranking initiative U-Multirank which includes data both from universities and from these universities' students. ${ }^{5}$ In sum, focus on quality for enhancement and accountability drive the

\footnotetext{
${ }^{4}$ Among the "Big Three" of international league tables-Academic Ranking of World Universities, Times Higher Education World University Rankings and QS World University Rankings - only the latter two actually include student data. At the moment it is only general information about student enrollments, the number of doctoral and international students.

${ }^{5}$ In U-Multirank, higher education institutions are asked to report data on students enrolled in degree programs, international students, new entrants of degree programs, students in internships, graduates and their employability. An important source of information for this ranking is a student survey, which is administered to 500 students in each field at participating institutions. The questionnaire is focused on student satisfaction and comprises questions aimed at evaluation of university services and quality of teaching.
} 
use of student surveys. This trend is accelerated by the increased competition for students in market-driven higher education systems.

\section{Overview of the Most Influential Student Experience and Engagement Surveys}

In this section we will explore theoretical foundations, content, measurements, data collection, analysis and the use of the major student engagement and experience surveys. Our attention will be focused on several system-wide and international "flagship" projects that have attracted attention due to their widespread use. Those are the National Survey of Student Engagement (NSSE) in the US and Canada (which has been adapted into a number of NSSE-based national surveys), the Student Experience in the Research Universities (SERU) survey in the US and internationally (SERU-AAU and SERU-I, respectively), the National Student Survey in the UK (NSS) and the Dutch National Student Survey in the Netherlands (NSE). ${ }^{6}$ The former two surveys were initiated by universities themselves over a decade ago with the purposes of inter-institutional comparison for institutional improvement. The latter two were introduced more recently by governmental agencies to increase higher education system's transparency, and to inform student choice of institutions and study programs. This reflects two different approaches to student surveys development (bottom-up vs. top-down) and affects their methodology and the uses of the data.

These four surveys have adjacent intellectual roots but base themselves upon different meaning of student experience. The underlying idea of NSSE and SERU is that student learning outcomes are affected by the characteristics of higher education institutions and their academic programs (Astin 1985; Pascarella and Terenzini 1991). Both put an emphasis on students' active engagement in educational practice as well as in extracurricular and civic activities, which they find equally important for student learning outcomes as the quality of institutional efforts to support student learning and development (Kuh 2001, 2003; McCormick et al. 2013). SERU survey specifically targets research universities (Kerr 2001). In its content SERU seeks to reflect the specific institutional characteristics of research universities by focusing on student engagement in three inter-related areas: teaching and learning, research and civic service. In contrast, NSS and NSE instruments are primarily concerned with the assessment of student course experience and seek to capture the various facets of the student learning process (Biggs 1987b; Prosser and Trigwell 1999; Ramsden 1979; Richardson 1983) by adapting instruments, such as the Ramsden's Course Experience Questionnaire (Ramsden 1991). They are focused

\footnotetext{
${ }^{6}$ Of course there are many more large scale student surveys worldwide (done by universities, ranking agencies and pollsters) but these projects are fairly representative of the cutting edge student engagement surveys in terms of their methodology, scope and data use.
} 
on quality assessment and measure student satisfaction with other aspects of teaching and learning organisation, support, and environment, ${ }^{7}$ and do not include measures of student engagement as students' own contribution to their learning and development.

Data collection and analysis procedures are similar for these four surveys, though target populations and response rates vary. All surveys are centrally administered (either by universities or independent companies) every year, and data is collected primarily through online platforms (NSSE and NSS additionally use paper-based questionnaires). All surveys are census-based. ${ }^{8}$ SERU and NSE include all undergraduate students in their target populations, NSSE-first- and last-year students and NSS - final-year students only. NSS stands out among other surveys with the average response rate of more than $70 \%$, while SERU, NSSE and NSE demonstrate 25-35\% average response rate. Data is centrally managed and analyzed in case of NSSE, NSS and NSE: participating institutions have access only to aggregated results of students' responses. SERU utilizes decentralized approach in data analysis and provides for benchmarking as all members of consortium share reciprocally their databases with each other.

The uses of the data in these four surveys are affected by their origins and scope: NSSE and SERU data is used by universities more for internal quality enhancement, whereas NSS and NSE data is targeted in particular at external agencies and stakeholders. Since institutions voluntarily participate in NSSE and SERU, the data is used for institutional self-improvement and quality assurance efforts through benchmarking. NSSE examples include voluntary accreditation, increasing retention rates, informing reorganization of student services, diversity initiatives, etc. (see NSSE 2009, 2012 for more examples). SERU is more focused on informing academic department program reviews, though it is also used campus-wide for voluntary accreditation, assessment of campus climate, analysis of admission policies, etc. (see SERU 2014a). The major difference between NSSE and SERU in terms of data use is that the former provides more information on various types of institutions (four-year colleges, teaching universities), while the latter is focused on research university environment and allows to address narrow problems of various student sub-groups valuable for large research universities. ${ }^{9}$ NSS and NSE data is used to inform prospective students' decision-making in higher education: the results are publicly available and are utilized in web-based platforms for comparing universities and academic programs. Universities also use this data to support internal discussions on teaching and learning, improve quality of student services as well as for marketing purposes. The major characteristics of these four surveys are summarized in Table 2.

\footnotetext{
${ }^{7}$ For a recent review of NSS methodology, see Callender et al. (2014).

${ }^{8} \mathrm{Few}$ institutions administer NSSE to a random sample of their students.

${ }^{9}$ For example, SERU will be useful for understanding the low level of research engagement among female junior transfer students majoring in STEM, as there is usually enough data for the comparison of such minority groups between institutions.
} 
Table 2 A comparison of major student engagement and experience survey designs

\begin{tabular}{|c|c|c|c|c|}
\hline & NSSE & SERU-AAU/SERU-I & NSS & NSE \\
\hline Goal & $\begin{array}{l}\text { To assess student } \\
\text { engagement in and } \\
\text { exposure to proven } \\
\text { educational practices } \\
\text { that correspond to } \\
\text { desirable learning } \\
\text { outcomes (NSSE } \\
\text { 2012) }\end{array}$ & $\begin{array}{l}\text { To understand student } \\
\text { experience in } \\
\text { research-intensive } \\
\text { universities and to } \\
\text { promote culture of } \\
\text { institutional } \\
\text { self-improvement (SERU } \\
\text { 2014b) }\end{array}$ & $\begin{array}{l}\text { To measure } \\
\text { students } \\
\text { satisfaction } \\
\text { with their } \\
\text { courses and to } \\
\text { help } \\
\text { prospective } \\
\text { students make } \\
\text { study choices } \\
\text { (NSS 2014) }\end{array}$ & $\begin{array}{l}\text { To assess } \\
\text { students' } \\
\text { experience and } \\
\text { satisfaction } \\
\text { with the higher } \\
\text { education } \\
\text { course they } \\
\text { pursue (NSS } \\
\text { 2014) }\end{array}$ \\
\hline $\begin{array}{l}\text { Participation } \\
\text { for } \\
\text { universities }\end{array}$ & Voluntary & Voluntary & $\begin{array}{l}\text { Obligatory for } \\
\text { publicly } \\
\text { funded } \\
\text { universities in } \\
\text { the UK }\end{array}$ & $\begin{array}{l}\text { Obligatory for } \\
\text { accredited } \\
\text { Dutch higher } \\
\text { education } \\
\text { institutions }\end{array}$ \\
\hline $\begin{array}{l}\text { Theoretical } \\
\text { foundations }\end{array}$ & $\begin{array}{l}\text { Student engagement } \\
\text { (Kuh 2001, 2003; } \\
\text { Pascarella and } \\
\text { Terenzini 2005) }\end{array}$ & $\begin{array}{l}\text { Input-environment-output } \\
\text { model (Astin 1985); } \\
\text { Research university (Kerr } \\
\text { 2001) }\end{array}$ & $\begin{array}{l}\text { Approaches to } \\
\text { learning } \\
\text { (Biggs, } \\
\text { 1987b; } \\
\text { Prosser and } \\
\text { Trigwell } \\
\text { 1999; } \\
\text { Ramsden } \\
\text { 1979, 1991; } \\
\text { Richardson } \\
\text { 1983) }\end{array}$ & $\begin{array}{l}\text { Multiple } \\
\text { instruments on } \\
\text { student } \\
\text { engagement, } \\
\text { satisfaction } \\
\text { and learning } \\
\text { outcomes }\end{array}$ \\
\hline $\begin{array}{l}\text { Survey } \\
\text { content: } \\
\text { topics }\end{array}$ & $\begin{array}{l}\text { Participation in } \\
\text { educationally } \\
\text { purposeful activities, } \\
\text { institutional } \\
\text { requirements of } \\
\text { coursework, } \\
\text { perceptions of the } \\
\text { college environment, } \\
\text { educational and } \\
\text { personal growth, etc. }\end{array}$ & $\begin{array}{l}\text { Academic, research and } \\
\text { civic engagement, time } \\
\text { allocation, learning } \\
\text { outcomes assessment, } \\
\text { campus climate, plans and } \\
\text { aspirations, satisfaction } \\
\text { with academic program, } \\
\text { global experiences, } \\
\text { learning and technology, } \\
\text { etc. }\end{array}$ & $\begin{array}{l}\text { Satisfaction } \\
\text { with teaching } \\
\text { quality, } \\
\text { assessment } \\
\text { and feedback, } \\
\text { academic } \\
\text { support, } \\
\text { organization } \\
\text { and } \\
\text { management, } \\
\text { learning } \\
\text { resources, } \\
\text { personal } \\
\text { development, } \\
\text { overall } \\
\text { experience, } \\
\text { etc. }\end{array}$ & $\begin{array}{l}\text { Content and } \\
\text { organization } \\
\text { of teaching, } \\
\text { acquired skills, } \\
\text { preparation for } \\
\text { career, } \\
\text { academic } \\
\text { guidance, } \\
\text { quality of } \\
\text { assessment, } \\
\text { contact hours, } \\
\text { internships, } \\
\text { quality of } \\
\text { learning } \\
\text { environment, } \\
\text { etc. }\end{array}$ \\
\hline $\begin{array}{l}\text { Survey } \\
\text { content } \\
\text { validity and } \\
\text { reliability } \\
\text { studies }\end{array}$ & $\begin{array}{l}\text { McCormick and } \\
\text { McClenney (2012), } \\
\text { Pascarella et al. } \\
\text { (2008), Pike (2013) }\end{array}$ & Chatman $(2009,2011)$ & $\begin{array}{l}\text { Callender } \\
\text { et al. (2014), } \\
\text { Richardson } \\
\text { et al. (2007) }\end{array}$ & $\begin{array}{l}\text { Brenders } \\
(2013)\end{array}$ \\
\hline
\end{tabular}


Table 2 (continued)

\begin{tabular}{|c|c|c|c|c|}
\hline & NSSE & SERU-AAU/SERU-I & NSS & NSE \\
\hline $\begin{array}{l}\text { Data } \\
\text { collection: } \\
\text { sample }\end{array}$ & $\begin{array}{l}\text { Census-based/random } \\
\text { sample survey of } \\
\text { first-year and senior } \\
\text { students }\end{array}$ & $\begin{array}{l}\text { Census-based survey of } \\
\text { undergraduate students }\end{array}$ & $\begin{array}{l}\text { Census-based } \\
\text { survey of last } \\
\text { year students }\end{array}$ & $\begin{array}{l}\text { Census-based } \\
\text { survey of } \\
\text { undergraduate } \\
\text { students }\end{array}$ \\
\hline $\begin{array}{l}\text { Data } \\
\text { collection: } \\
\text { method and } \\
\text { frequency }\end{array}$ & $\begin{array}{l}\text { Online and } \\
\text { paper-based; once a } \\
\text { year }\end{array}$ & Online; once a year & $\begin{array}{l}\text { Online and } \\
\text { paper-based; } \\
\text { once a year }\end{array}$ & $\begin{array}{l}\text { Online; once a } \\
\text { year }\end{array}$ \\
\hline $\begin{array}{l}\text { Data } \\
\text { collection: } \\
\text { response } \\
\text { rates }\end{array}$ & $25-30 \%$ & $25-30 \%$ & $71 \%$ & $34 \%$ \\
\hline \multirow[t]{2}{*}{ Data analysis } & Centralized approach & Decentralized approach & $\begin{array}{l}\text { Centralized } \\
\text { approach }\end{array}$ & $\begin{array}{l}\text { Centralized } \\
\text { approach }\end{array}$ \\
\hline & $\begin{array}{l}\text { Engagement indicators } \\
\text { (benchmarks) and item } \\
\text { by item comparisons }\end{array}$ & $\begin{array}{l}\text { Factor scores and item by } \\
\text { item comparisons }\end{array}$ & $\begin{array}{l}\text { Item by item } \\
\text { comparisons }\end{array}$ & $\begin{array}{l}\text { Item by item } \\
\text { comparisons }\end{array}$ \\
\hline Data use & $\begin{array}{l}\text { Mostly internal: for } \\
\text { benchmarking, } \\
\text { voluntary } \\
\text { accreditation, } \\
\text { decision-making } \\
\text { support }\end{array}$ & $\begin{array}{l}\text { Mostly internal: for } \\
\text { program review, voluntary } \\
\text { accreditation, } \\
\text { decision-making support }\end{array}$ & $\begin{array}{l}\text { Mostly } \\
\text { external: to } \\
\text { inform } \\
\text { prospective } \\
\text { students' } \\
\text { choice of the } \\
\text { academic } \\
\text { program, to } \\
\text { create league } \\
\text { tables, for } \\
\text { marketing } \\
\text { purposes }\end{array}$ & $\begin{array}{l}\text { Mostly } \\
\text { external: to } \\
\text { inform } \\
\text { prospective } \\
\text { students' } \\
\text { choice of the } \\
\text { academic } \\
\text { program, for } \\
\text { marketing } \\
\text { purposes }\end{array}$ \\
\hline
\end{tabular}

\section{Methodological Limitations of Student Engagement and Experience Surveys}

The widespread use of student experience and engagement survey data raises questions of reliability, validity and other quality characteristics of such data to be used as evidence in higher education decision-making. Validity concerns "whether the surveys measure what they are designed to measure and to provide evidence that supports inferences about the characteristics of individuals being tested" (OECD 2013 , p. 12). The key aspect of validation of the survey instrument lies in assessing whether the assumptions which are included in the theory defining the construct (in this case student satisfaction/student experience and student engagement) are credible. Reliability concerns whether surveys "provide stable and consistent results over repeated measures allowing for results to be replicable across different testing situations?" (OECD 2013, pp. 12-14). Here the focus is much more on questions such as how respondents respond to the questions, i.e. if the interpretation of 
questions is consistent among participants, but also the guidelines for administering the survey and scoring individual items. In this section we synthesise the key points of criticism and the defence of student surveys with specific focus on student engagement surveys. We believe that decision makers ought to be aware of these discussions as to be able to evaluate the rigorousness and appropriateness of the specific survey instruments at their hand.

Critics point to two major areas of contention in the student engagement surveys: (1) accuracy of student self-reported information on engagement and learning gains, and (2) the selection of the standards of educational practice and student behaviour implied in the questions (Campbell and Cabrera 2011; Gordon et al. 2008; Porter 2013; Porter et al. 2011). The proposition on the former is that cognitive abilities of students to comprehend the survey question and retrieve the information are often overestimated by survey designer. On this point Porter (2011, p. 56) illustratively suggests that the surveys are built with the view of students "as having computer hard drives in their head allowing them to scan the reference period of matching behaviour, process it and provide an answer of the frequency of the behaviour". Particular criticism of the student engagement surveys concerns students' ability to make an informed judgment of their self-reported learning gains, i.e. growth in knowledge, skills, abilities, and other attributes that they have gained during studentship. Porter et al. (2011) offer empirical evidence as to the inaccuracy of the self-reported learning gains. They argue that such types of questions are highly susceptible to social desirability bias (ibid.). When students wish to provide an answer in the survey, but cannot retrieve information, they resort to intelligent guessing, often based on what they think should be happening or to make them look favourable to others (Porter 2011).

Another criticism is in the selection of the standards of institutional practice and student behaviour, i.e. the factors that are expected to influence student learning and development, implied in the survey questions, and how these relate to other external measures. The important question here is what is measured and what is not. Standardised surveys imply an established (fixed) standard of process or outcome against which institutions are evaluated and need to demonstrate conformity (Ewell 2009). This raises a question of how these "standards" have been established: have they been derived from theory, from other empirical findings, or they reflect certain policy objectives. Survey research is prone to observational biases when researchers look "where they think they will find positive results, or where it is easy to record observations", i.e. the so-called 'streetlight effect' coined by Friedman (2010) after the joke of a drunken man who lost his key and is looking under the streetlight since that is where the light is. In this respect, surveys tend to give more attention to institutional factors that shape student experience and less to the other contextual and psycho-socioecological factors, which are much more difficult to measure, such as the role of broader socio-cultural context, university culture, family support, psycho-social influences (Kahu 2013), emotions (Beard et al. 2007; Kahu 2013), student and academic identities, and disciplinary knowledge practices (Ashwin 2009). 
A problem specific to inter-institutional and system-wide surveys lies in the level of contextualisation. To allow for comparisons, these surveys are conceived in a generic and highly abstract way. This proves it difficult to adequately account for the organisational differences between institutions in terms of their specific missions and objectives, resources, profiles of student population, and various unique arrangements that give each and every institution certain distinct flavour. If the survey tool is generic enough as to allow for comparison of very different institutions in a national system or internationally, then their use by any of the intended users - institutions, students or governments - is fairly limited. In their generic form these surveys cannot discern the contextual dimensions and variables which could add most value to a formative use of such data. International comparisons or international adaptations of the instruments initially developed for a particular higher education system (such as the US or Australia or the UK) present a number of challenges associated with adequate translation and cultural localization of survey items. More contextualised variations of survey design are developed when very similar institutions are compared and the lower we go within institutional hierarchy, i.e. to the program level.

The rebuttals of the criticism are equally numerous. The key response to the criticism regarding the accuracy of self-reported learning gains is that surveyssuch NSSE - never claimed to collect precise responses about either learning gains or behaviours, but are based on the principle of a reasoned and informed judgement, which allows the institutions to use the data to screen major occurrences and major trends over time and across institutions (Ewell 2009; McCormick and McClenney 2012; Pike 2013). The criticism regarding the selection of "benchmarks" has been refuted by pointing out that major surveys rely on interviews and focus groups both in formulating and in pilot-testing the questions. The key focus of these qualitative appraisals is precisely to test participants' understanding and the consistency of interpretation of the questions (McCormick and McClenney 2012; Pike 2013). Pike (2013) notes that the primary use of student surveys is often ignored by the critics and that major validation lies in these surveys' appropriateness for institution- and group-level decision-making. In the case of NSSE he offers empirical evidence that the NSSE benchmarks can be used to assess the extent to which an institution's students are engaged in educationally purposeful activities, and the extent to which colleges and universities are effective in facilitating student engagement (Pike 2013). Furthermore, several authors highlight that the survey benchmarks were designed so as to "represent clusters of good educational practices and to provide a starting point for examining specific aspects of student engagement" (Ewell et al. 2011; Kuh 2001; McCormick and McClenney 2012; Pike 2013, p. 163).

Furthermore, a welcome modification has been in longitudinal designs with repeated measure which allow for tracking changes in student behaviour and perceptions of student experience over time. Another helpful revision to the survey designs has been done by introducing the questions of student expectations and aspirations to surveys targeted at students at the beginning of their study. Importantly, longitudinal designs have also been extended into the labour market since the effects of educational provision on students may better reveal upon 
completion of studies (cf. Kim and Lalancette 2013). Promising complementary research lies in student social network analyses which depict a complex web of relationships and interactions, both historic and present, both within and outside academic settings, both physical and virtual, that shape individual students' (perception of) learning and experience (Biancani and McFarland 2013).

One implication of the eagerness of institutional decision makers and policy makers to collect data directly from students is survey fatigue. Students are more and more tired of surveys, complete them carelessly or do not complete them at all. Institutional surveys compete with hundreds of other surveys (including those by business eager to understand the millennials' consumer habits) and students do not differentiate between them or do not care to respond. Low response rates accentuate possible biases in survey responses; the most common among them is underrepresentation of disengaged, non-traditional and minority students. Low response rate remain major challenge in the student survey methodology despite ample attempts devoted to find better ways to raise response rates (Porter 2004; Porter and Whitcomb 2004; Porter et al. 2004). Inevitably, we will need to look for new ways of collecting data from students on their behaviour, preferences and opinions.

In sum, there are convincing arguments on both sides. Obviously, researchers ought to continue to work towards improving student survey instruments, as such data is helpful for our better understanding of how students experience higher education and for devising interventions for improvements. While survey data is an important source of evidence, it is by no means sufficient. As mentioned by Alderman et al. (2012, p. 273), greater reliability of data is achieved when student survey data are used "in conjunction with information from other sources and robust links are established between the data and the institution's overall quality management system". For the purposes of formative decision-making oriented towards the institutional and program improvements, student data needs to come from several sources and be validated through cross verification of data from different sources (i.e. triangulated). At best student surveys are used as screening instruments to discover major deficiencies in educational environment and provision, and major discrepancies in student behavior from the expected. Such diagnostic results in turn guide the institutional managers to explore causes and consequences of various practices and processes. This is done through qualitative methods which can generate contextualized data-indeed richer, deeper and more authentic data - on student experience and behaviour albeit on smaller scale, by focusing on the 'particular'.

The advantage of qualitative methods is that they can generate richer, deeper and more authentic data on student experience and behaviour. However, their major drawback is in limited scope - they focus on particular case or phenomenon, which makes generalisations to large populations problematic. The intensive field-work (through in-depth interviews, focal groups, direct observation, etc.) makes it simply too time-consuming and too costly to reach large numbers of students. The question that arises is whether, with the use of new technology, the universal use of social media by students and the advances in big data science, these limitations could be overcome. Frontier research agendas lie in exploring digital adaptations of 
qualitative research methods of data collection, such as digital ethnography and digital phenomenology, which give access to more contextualized data on human behavior and lived-experiences on a large scale (Klemenčič 2013). It is plausible to expect that, in the very near future, data on student experience will be collected from students not through invitations to answer on-line student surveys but ratherseamlessly and in great volumes - through social media platforms adapted to use by institutional researchers (Klemenčič 2013). Advancements in educational technology and students' near universal use of mobile technology present enabling conditions for such innovation. The major challenge to this promising method, however, lies in safeguarding of private or individually identifying information and other ethical concerns that arise from research using Internet.

Before we continue to describe the various approaches to student data analytics, one concession is in place. Student data analytics to generate evidence for decision-making is inevitably reductionist: it means capturing aspects of student experience which are general to most students, rather than particular to a few. There is no way that we can turn every idiosyncratic aspect of individual student experience into evidence that can inform institution-wide or system-wide decisions. Against, best what we can do as researchers and decision-makers who seek "intelligence" for their decisions, is to utilize data from several sources and obtained from both quantitative and qualitative methods.

\section{Student Surveys as Part of the Development of Student Data Analytics in Institutional Research}

This section focuses on the challenges and opportunities concerning student data analytics as part of the institutional research: the practices of collecting, synthesizing, and analyzing student data to serve as evidence in university decision-making and planning, and also to fulfill mandatory reporting requirements and external assessment (cf. Klemenčič and Brennan 2013; Klemenčič et al. 2015). The institutional research on students is part of the larger process of expanding the function of institutional research from the basic reporting approach for statistical purposes, funding and accreditation and record keeping towards a bigger role in quality assurance, assessment of institutional performance, and, ultimately, also in strategic planning and development (Klemenčič et al. 2015). The development of institutional approaches to student data analytics towards the strategic approach requires several changes in terms of types of data collected, sources of data and data management systems (see Fig. 1).

As we move from reporting approach towards quality and strategic approaches, the range of student data collected expands: from the basic records on enrollments, academic progress and student profile to student course evaluations, student approaches to studying and learning, student satisfaction with the learning environment (student services and facilities) as well as student learning outcomes and 


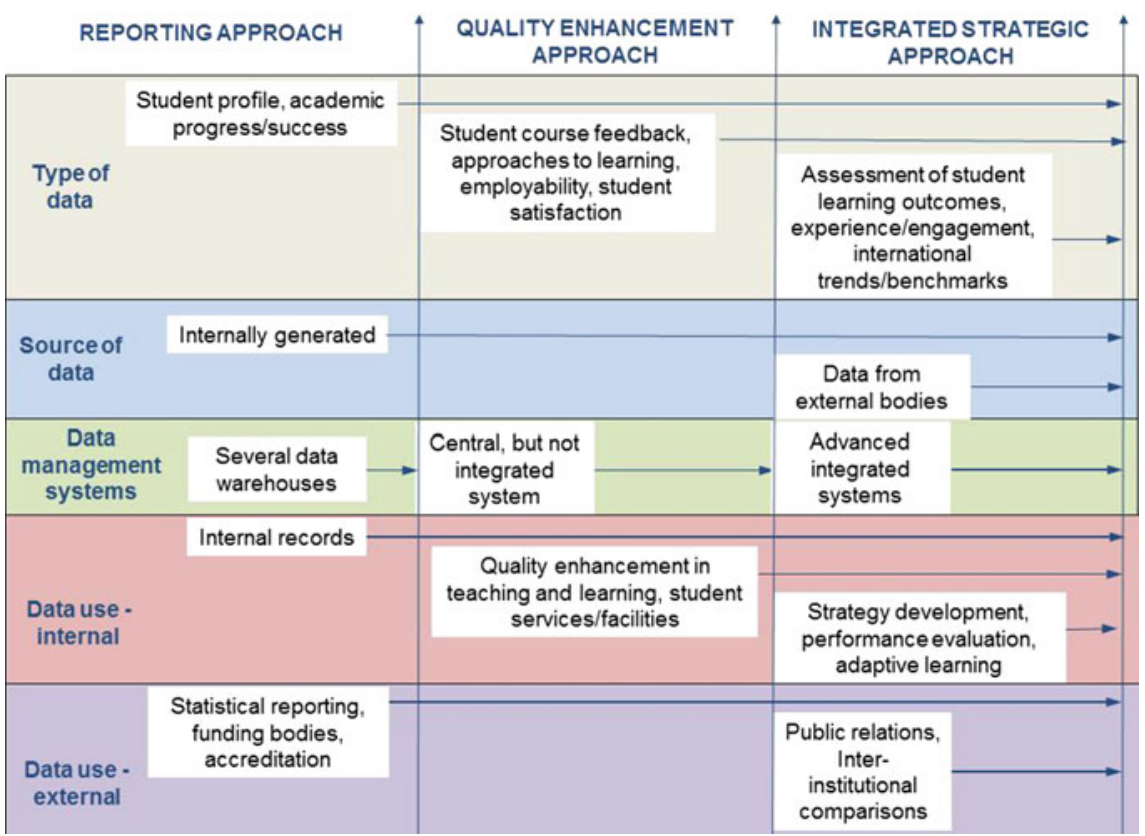

Fig. 1 Approaches to student data analytics

employability. In reporting approach, data tend to be generated only from the institutional records provided by students upon registration and from student academic records. In quality enhancement approach, data is also sought directly from students with surveys on opinions, satisfaction and behavior, and possibly also through qualitative methods, such as interviews, focal groups or direct observation. In strategic approach institutions also gather data from external data sources to develop intelligence on international trends in student recruitment, and compare themselves to other institutions. They use new technologies which allow for data mining and data scraping to extract information from public data sets, social media and public blog posts. Another new source of data on student behavior comes with web analytics which track students' usage of university webpages.

Data on and from students typically presents one of the sources of university intelligence, and it varies from one institution to another to which extent this data is integrated into a central data warehouse and translated into "business intelligence" to inform decision-making, or is kept within warehouses of student registrars or quality assurance centers of teaching and learning units. Methods of data management-collection, storage and analysis-differ in the reporting, quality and strategic approaches. In reporting approach, different types of data are kept in individual data warehouses units (e.g. student registrars, units for quality assurance, student affairs, teaching and learning, international office, etc.) and processes within that unit. Data is automated and processed with basic statistical tools. Standardized reports are prepared for internal or external use. In quality approach, data tends to 
be managed within different units, but a central data management system is put into place to conduct quality checks and prepare institution-wide reports. In strategic approach, institutions connect student data from various sources into one integrated institutional data warehouse, where it is linked also to other data on university operations (e.g. academic staff, finance, etc.). The advantage of such integrated systems is that student data - and other key institutional data - is available across the institution and processed in a timely and reliable manner through common data management software. In this way data is accessible across the institution for performance evaluation and strategy planning. For such data managements systems to work, universities first of all need to build technical capacity, but-also and equally important - hire and train skilled analytic professionals who are able to turn data into evidence for decision-making (Klemenčič et al. 2015). Often in universities there already exist much reliable data and information, which is not put into use in decision-making, because it is not readily and easily accessible or because it is not sufficiently processed for use.

\section{Recommendations to Policy Makers}

Student survey data has been used to generate evidence on what works and what does not work in how higher education institutions conduct teaching and enable learning and development. This evidence is to serve several purposes and users: it is to inform policy and practice of institutions themselves, it is to inform policy of governments, and it is to inform the higher education stakeholders, first and foremost students and their families. Given the vast implications of the use of survey data as evidence and as information in decision processes, student survey data and methods to collect student data ought to be scrutinized for reliability and validity. There are several quality standards that can serve as guidance in designing student surveys and in evaluating quality of survey data (cf. Alderman et al. 2012; Harvey 2003; Porter 2004; Richardson 2005):

1. Surveys have an explicit stated purpose which leads to quality enhancement. They are tailored to that specific purpose (Alderman et al. 2012).

2. Student feedback is sought "at the level at which one is endeavouring to monitor quality", as soon as possible after the relevant educational activity (Richardson 2005 , p. 409), and ideally repeatedly to monitor trends.

3. The survey instruments that aim at inter-institutional comparisons serve best as screening tools when two conditions are met: (i) the more alike the compared institutions are in their mission, purpose and resources, and (ii) the lower in the institutional hierarchy is the unit of analysis (surveys on the program level are the most desirable points of comparison).

4. Students and other stakeholders are involved in the entire process of survey design, implementation, analysis and reporting to aid relevance, clarity, and legitimacy of surveys. 
5. Survey design is critically appraised as to the underlying ideological and policy frames: How different values are negotiated and balanced and reflected in the survey instruments? What value-signals the institution is sending through the questionnaires? Such critical reflexive processes can be more fruitful if different epistemic communities are involved in it; especially students who are directly affected by the policy interventions, and who have the first-hand experience of practice (cf. Klemenčič and Brennan 2013).

6. If there are several surveys administered by the institution, possibilities are explored to integrate them. The different surveys are checked for possible conflicts in timing of administration, duplication of questions, etc.

7. To raise response rates, several methods have been recorded to increase response rates: multiple contacts; incentives included with survey instrument (not conditional on completion); (statement of) high survey salience to students; and request for help in the cover letter (Porter 2004).

8. Participants in the survey are aware of how the data will be used, i.e. the feedback loop. This may raise survey salience, i.e. the importance or relevance that students attribute to the survey topic, which is shown to raise response rates (Porter 2004).

At best, student surveys are used as screening instruments to discover major deficiencies in educational environment and provision, and major discrepancies in student behavior from the expected. Such diagnostic results in turn guide the institutional managers to explore causes and consequences of various practices and processes. This is done through qualitative methods which can generate contextualized data - indeed richer, deeper and more authentic data - on student experience and behaviour albeit on smaller scale, by focusing on the 'particular'. With the advancement in new technology and the universal use of digital media by students (Gardner and Davis 2013), research is already underway seeking to adapt qualitative empirical methods to digital use, to canvass data on student experience on a large scale (such as digital ethnography and digital phenomenology by Klemenčič 2013); and more exploratory and innovative research in this area is called for.

The rise of big data on students will make institutional research more complex and challenging. Institutional researchers will need to learn how to leverage data resources effectively to support decision-making. From basic student records, which have become automatized, the attention is shifting to 'issue intelligence' and 'contextual intelligence' to aid policy and strategic planning, including forecasting and scenarios building (Klemenčič and Brennan 2013). Along with the questions of what constitutes sound evidence for policy-making, more attention is devoted to institutional capacities for institutional research and data analytics to support decision-making.

Acknowledgment Support to Igor Chirikov from the Basic Research Program of the National Research University Higher School of Economics is gratefully acknowledged. The authors would like to thank Paul Ashwin for most helpful feedback to the earlier draft. 
Open Access This chapter is distributed under the terms of the Creative Commons Attribution Noncommercial License, which permits any noncommercial use, distribution, and reproduction in any medium, provided the original author(s) and source are credited.

\section{References}

Alderman, L., Towers, S., \& Bannah, S. (2012). Student feedback systems in higher education: A focused literature review and environmental scan. Quality in Higher Education, 18(3), 261280.

Ashwin, P. (2009). Analysing teaching-learning interactions in higher education: accounting for structure and agency. London: Continuum.

Astin, A. W. (1985). Achieving educational excellence. San Francisco: Jossey-Bass.

Beard, C., Clegg, S., \& Smith, K. (2007). Acknowledging the affective in higher education. British Educational Research Journal, 33(2), 235-252.

Biancani, S., \& McFarland, D. A. (2013). Social networks research in higher education. In M. B. Paulsen (Ed.), Higher education: Handbook of theory and research (Vol. 28) (Vol. 151215). Dordrecht, The Netherlands: Springer.

Biggs, J. B. (1987a). Learning process questionnaire manual. Student approaches to learning and studying. Hawthorn, Vic: Australian Council for Educational Research.

Biggs, J. B. (1987b). Student approaches to learning and studying. Camberwell, Vic: Australian Council for Educational Research.

Biggs, J. B. (1987c). Study process questionnaire manual. Student approaches to learning and studying. Hawthorn, Vic: Australian Council for Educational Research.

Brenders, P. (2013). Response, reliability, and validity of the Dutch national student survey. Paper presented at the EAIR 35th Annual Forum in Rotterdam, Netherlands.

Callender, C., Ramsden, P., \& Griggs, J. (2014). Review of the national student survey. London: HEFCE.

Campbell, C. M., \& Cabrera, A. F. (2011). How sound is NSSE? Investigating the psychometric properties of NSSE at a public, research-extensive institution. The Review of Higher Education, 35(1), 77-103.

Chatman, S. (2009). Factor structure and reliability of the 2008 and 2009 seru/ucues questionnaire core. SERU Project Technical Report.

Chatman, S. (2011). Factor structure and reliability of the 2011 seru/ucues questionnaire core. SERU Project Technical Report.

Coates, H. (2005). The value of student engagement for higher education quality assurance. Quality in Higher Education, 11(1), 25-36.

Coates, H. B., \& Lennon, M. C. (2014). Propelling the field: Insights, trends and prospects. In H. Coates (Ed.), Higher education learning outcomes assessment: International perspectives. Frankfurt: Peter Lang.

Coates, H. B., \& McCormick, A. C. (Eds.). (2014). Engaging university students: International insights from system-wide studies. Singapore: Springer.

ETS, Educational Testing Service. (2014). Proficiency Profile.

Ewell, P. T. (2009). Assessment, accountability, and improvement: Revisiting the tension. Occasional paper no 1. Champaign, Illinois: National Institute for Learning Outcomes.

Ewell, P. T., McClenney, K., \& McCormick, A. C. (2011). Measuring engagement inside higher education. Retrieved from https://www.insidehighered.com/views/2011/09/20/measuringengagement.

Friedman, D. H. (2010). Why scientific studies are so often wrong: The streetlight effect. Discover Magazine (December 10 ed.).

Gardner, H., \& Davis, K. (2013). The app generation: How today's youth navigate identity, intimacy, and imagination in a digital world. New Haven: Yale University Press. 
Gordon, J., Ludlum, J., \& Hoey, J. J. (2008). Validating the NSSE against student outcomes: Are they related? Research in Higher Education, 2008(49), 19-39.

Hall, P. A., \& Lamont, M. (2009). Successful societies: How institutions and culture affect health. Cambridge: Cambridge University Press.

Harvey, L. (2003). Student feedback. Quality in Higher Education, 9(1), 1-20.

Kahu, E. (2013). Framing student engagement in higher education. Studies in Higher Education, $38(5), 758-773$.

Kerr, C. (2001). The uses of the university (5th ed.). Cambridge, MA: Harvard University Press.

Kim, H. H., \& Lalancette, D. (2013). Literature review on the value-added measurement in higher education. Retrieved from http://www.oecd.org/edu/skills-beyond-school/Litterature\% 20Review\%20VAM.pdf.

Klemenčič, M. (2013). A "new" phenomenology of student experience and engaging students in institutional research. Paper presented at the EAIR, Track: Student learning and student experience, Rotterdam

Klemenčič, M. (2015). What is student agency? An ontological exploration in the context of research on student engagement. In M. Klemenčič, S. Bergan, \& R. Primožič (Eds.), Student engagement in Europe: Society, higher education and student governance (pp. 11-29). Strasbourg: Council of Europe Publishing.

Klemenčič, M., \& Brennan, J. (2013). Institutional research in a European context: A forward look. European Journal of Higher Education, 3(3), 265-279.

Klemenčič, M., Šćukanec, N., \& Komljenovič, J. (2015). Decision support issues in central and eastern Europe. In Karen Webber \& Angel Calderon (Eds.), Institutional Research and planning in higher education: Global contexts and themes (pp. 71-85). New York: Routledge Press/Taylor \& Francis.

Kuh, G. D. (2001). The National Survey of Student Engagement: Conceptual framework and overview of psychometric properties. Bloomington, IN: Indiana University, Center for Postsecondary Research.

Kuh, G. D. (2003). What we're learning about student engagement from NSSE. Change, 35(2), 24-32.

Kuh, G. D. (2009). The national survey of student engagement: Conceptual and empirical foundations. New Directions for Institutional Research, 2009(141), 5-20.

Loukolla, T., \& Zhang, T. (2010). Examining quality culture: Part I-Quality assurance processes in higher education institutions. Brussels: European University Association.

Marginson, S. (2014). Higher education as self-formation. Paper presented at the Lecture at Higher School of Economics' Summer School, St Petersburg.

McCormick, A. C., Kinzie, J., \& Gonyea, R. M. (2013). Student engagement: Bridging research and practice to improve the quality of undergraduate education. In M. B. Paulsen (Ed.), Higher education: Handbook of theory and research (Vol. 28, pp. 47-92). Dordrecht, The Netherlands: Springer.

McCormick, A. C., \& McClenney, K. (2012). Will these trees ever bear fruit? A response to the special issue on student engagement. Review of Higher Education, 35(2), 307-333.

NSS, National Student Survey. (2014). What is the NSS? Retrieved from http://www. thestudentsurvey.com/the_nss.html.

NSSE, National Survey of Student Engagement. (2009). Using NSSE Data to Improve Undergraduate Education. Lessons from the Field. Volume 1. Bloomington, IN: Indiana University Center for Postsecondary Research.

NSSE, National Survey of Student Engagement. (2012). Moving from Data to Action: Lessons from the Field-Volume 2. Bloomington, IN: Indiana University Center for Postsecondary Research.

OECD, Organisation for Economic Cooperation and Development. (2013). Assessment of higher education learning outcomes. Feasibility study report. Volume 2-Data Analysis and National Experiences. Paris: OECD.

Pascarella, E. T., \& Terenzini, P. T. (1991). How college affects students. San Francisco: Jossey-Bass. 
Pascarella, E. T., \& Terenzini, P. T. (2005). How college affects students (Vol. 2): A third decade of research. San Francisco: Jossey-Bass.

Pascarella, E. T., Seifert, T. A., \& Blaich, C. (2008). Validation of the NSSE benchmarks and deep approaches to learning against liberal arts outcomes. Paper presented at the Annual Meeting of the Association for the Study of Higher Education, Jacksonville, FL.

Pike, G. R. (2013). NSSE benchmarks and institutional outcomes: A note on the importance of considering the intended uses of an instrument in validity studies. Research in Higher Education, 2013(54), 149-170.

Porter, S. R. (2004). Raising response rates: what works? New Directions for Institutional Research, 2004(121), 5-21.

Porter, S. R. (2011). Do college student surveys have any validity? Review of Higher Education, 35(1), 45-76.

Porter, S. R. (2013). Self-reported learning gains: A theory and test of college student survey response. Research in Higher Education, 2013(54), 201-226.

Porter, S. R., Rumann, C., \& Pontius, J. (2011). The validity of student engagement survey questions: Can we accurately measure academic challenge? New Directions for Institutional Research, 2011(150), 87-98.

Porter, S. R., \& Whitcomb, M. E. (2004). Understanding the effect of prizes on response rates. New Directions for Institutional Research, 2004(121), 51-61.

Porter, S. R., Whitcomb, M. E., \& Weitzer, W. H. (2004). Multiple surveys of students and survey fatigue. New Directions for Institutional Research, 2004(121), 63-73.

Prosser, M., \& Trigwell, K. (1999). Understanding learning and teaching. Buckingham: Open University Press.

Radwin, D. (2009). High response rates don't ensure survey accuracy (October 5 ed.): Chronicle of Higher Education.

Ramsden, P. (1979). Student learning and perceptions of the academic environment. Higher Education, 8(4), 411-427.

Ramsden, P. (1991). A performance indicator of teaching quality in higher education: The course experience questionnaire. Studies in Higher Education, 16(2), 129-150.

Richardson, J. T. E. (1983). Student learning in higher education. Educational Psychology, 1983 (3), 305-331.

Richardson, J. T. E. (2005). Instruments for obtaining student feedback: a review of the literature. Assessment \& Evaluation in Higher Education, 30(4), 387-415.

Richardson, J. T. E. (2013). The national student survey and its impact on UK higher education. In M. Shah \& C. Nair (Eds.), Enhancing student feedback and improvement systems in tertiary education. Abu Dhabi: Commission for Academic Accreditation, UAE.

Richardson, J. T. E., Slater, J. B., \& Wilson, J. (2007). The national student survey: Development, findings and implications. Studies in Higher Education, 32(5), 557-580.

SERU, Student Experience in the Research University. (2014a). Uses of data from the UCUES and SERU survey: UC Berkeley Center for Studies in Higher Education.

SERU, Student Experience in the Research University. (2014b). SERU mission. Retrieved from $\mathrm{http}: / /$ www.cshe.berkeley.edu/SERU/seru-mission.

Shavelson, R. J. (2010). Measuring college learning responsibly. Accountability in a new era. Stanford: Stanford University Press.

Williams, J. (2014). Student feedback on the experience of higher education. A significant component of institutional research data. In M. E. Menon \& et al. (Eds.), Using data to improve higher education (pp. 67-80). Dordrecht: Sense Publishers. 